\title{
From Fear of Floating to Benign Neglect: The Exchange Rate Regime Roller Coaster in Pakistan
}

\author{
Syed Kumail Abbas Rizvi* , Bushra Naqvi ${ }^{* *}$, Nawazish Mirza ${ }^{* * *}$
}

\begin{abstract}
One of the most pressing issues concerning policymakers today is the choice of an exchange rate regime. Despite the intricacies of this problem, monetary authorities could narrow down their list of options if they were to focus on the following principles: full implementation to ensure credibility and synchronization with domestic realities and economic infrastructure. This paper proposes an optimal exchange rate regime for Pakistan based on a historical study of the outcomes and performance of different monetary stances adopted over the last 40 years.
\end{abstract}

Keywords: Exchange rate, flexibility, regime, fear of floating, floating, pegging, Pakistan.

JEL classification: E42, E58, F31, F33, F41.

\section{Introduction}

Perhaps no question has initiated as much debate in the literature on international finance as the adoption of an optimal exchange rate regime. The choice of exchange rate regime is complex for many reasons. First, the decision is not simply restricted to choosing between a fixed and floating exchange rate regime, rather it is a continuum of choices ranging from pegs to target bands to floats with varying degrees of intervention. Second, irrespective of the choices available under exchange rate flexibility, the behavior of an exchange rate in practice may diverge considerably from its de jure classification. Finally, the lack of consensus concerning the unambiguous theoretical relationship between exchange rate regimes and macroeconomic performance makes it even more difficult for a monetary authority to choose a regime.

While recent world trends suggest that floating exchange rates have become more desirable in advanced economies, emerging economies cannot

\footnotetext{
* Associate Professor of Finance, Lahore School of Economics.

*** Assistant Professor of Finance, Lahore University of Management Sciences.

**** Associate Professor of Finance, Lahore School of Economics.
} 
afford to adopt an attitude of "benign neglect" $(\mathrm{BN})^{1}$ and are thus forced to control and target their exchange rates. The rationale for this is the high cost attached to the vulnerability of the exchange rate. These costs arise for three main reasons. First, exchange rate vulnerability can lead to capital flight, in turn threatening the domestic currency (Mishkin, 2000). Second, currency depreciation will amplify the burden of debt denominated in a foreign currency while simultaneously reducing the value of assets denominated in the domestic currency; this reduces the net worth of the economy (Calvo, 2000). Third, emerging-market countries are more likely to find that depreciations lead to a rise in inflation as a result of the pass-through from higher import prices (Mishkin, 2004).

Not surprisingly, as an emerging economy Pakistan has always found the adoption of an exchange rate regime to be a difficult choice. The country followed a fixed-peg exchange rate regime up to the early 1980s. The State Bank of Pakistan (SBP) decided to abandon the pegged regime once it started working on comprehensive financial sector reforms with the help of the International Monetary Fund (IMF) and World Bank in the late 1980s. As a consequence of this initiative, the de jure exchange rate regime shifted to a managed float till 2000 and a free float thereafter. Notwithstanding the floating regime, it is frequently reported that the behavior of the exchange rate in Pakistan diverges significantly from its de jure classification.

Given the dilemma of choosing an exchange rate policy on one hand and adhering to the assertion of the central bank on the other, the objective of this study is threefold. First, we look at the different exchange rate regimes Pakistan has adopted and assess their economic and financial performance and outcomes in the form of certain macroeconomic indicators. Second, we assess the credibility of the central bank in maintaining its chosen exchange rate regime: the detection of the so-called "fear of floating" (FOF). Third, if the behavior of the exchange rate is found to be inconsistent with the stated exchange rate policy, we examine possible reasons for such inconsistencies and, more importantly, whether these inconsistencies benefit or harm the overall economy. We also propose an optimal exchange rate regime for Pakistan based on other macroeconomic and financial realities.

\section{An Analysis of the Data}

The annual data for 1961 to 2013 comprise several macroeconomic and financial indicators taken from the World Bank database. However,

${ }^{1}$ See Miskhin (2000): Watching your exchange rate depreciating, whether or not corresponded by the fundamentals, and doing nothing. 
for analysis purposes, we have included only the observations from 1975 and onward because of the extreme inconsistencies in the data resulting from the structural changes to the economy that followed the separation of East and West Pakistan in 1971.

\subsection{A Policy Overview}

The comprehensive financial sector reforms undertaken in the late 1980s with the help of the IMF and World Bank proved to be a turning point for the monetary sector in two respects. First, the SBP was assigned sole responsibility for making and conducting monetary policy in 1994. Second, Pakistan adopted market-based or indirect instruments of monetary policy where, previously, the SBP had relied on administered monetary policy regimes governed by ad hoc changes in the reserve ratio, directed credit, and regulated interest rate policies.

The SBP adopted monetary aggregate targeting in 1994, assuming a stable money demand function for Pakistan, which continues to date. The goals of monetary policy under this framework are inflation reduction (maintaining price stability) and output growth with broad money (M2) as the intermediate target and base or reserve money as the operational target. With the adoption of market-based instruments, more attention was paid to managing the short-term interest rate. The SBP adopted the three-day SBP discount rate as its major policy instrument to signal an easing or tightening of monetary policy.

Pakistan followed a fixed-peg exchange rate regime up to the early 1980s, after which it was abandoned in order to initiate an important transmission mechanism of monetary policy. As a result of this policy shift, the de jure exchange rate regime evolved into a managed float till 2000 and became free floating thereafter (Khan \& Qayyum, 2007).

\subsection{Categorizing Different Exchange Rate Regimes}

We divide our sample period of 1975 to 2013 into four exchange rate regimes (see Table 1 and Figure 1). The period 1975-81 is considered a pegged regime with an exchange rate of PKR $9.90=\$ 1$. The period 19822000 is classified as a managed float as per the SBP's official stance. The third regime, a floating exchange rate or free/pure float, officially started in 2001 and continues to date; this is broken down into two sub-regimes.

During 2001-07, despite the free-floating regime the exchange rate remained almost stagnant at PKR 60 against $\$ 1$. This sub-period is 
categorized as float-FOF where we presume that FOF behavior explains the almost constant exchange rate under the pure floating regime that was officially in place. In the second sub-period (2008 to date), the rupee lost almost 75 percent of its worth and jumped from PKR 60 to almost PKR 105 against the US dollar. This period is denoted as float-BN to indicate the "benign neglect" of the monetary authorities in allowing market forces to decide freely the equilibrium exchange rate between the rupee and the dollar. Although this nonintervention was commendable on paper and was synchronized with the SBP's official stance of a pure float, it has had serious repercussions that should have been anticipated and resolved by the monetary authorities.

Table 1: PKR-USD exchange rate volatility under different regimes

\begin{tabular}{llccr}
\hline Period & Regime & Exchange rate (mean) & Exchange rate (SD) & Obs. \\
\hline 2008-13 & Float-BN & 87.639690 & 12.100560 & 6 \\
2001-07 & Float-FOF & 59.740730 & 1.429629 & 7 \\
1982-2000 & Managed float & 27.043340 & 12.770980 & 19 \\
1975-81 & Pegged & 9.900000 & 0.000000 & 7 \\
& & & & 39 \\
\hline
\end{tabular}

Source: Authors' estimates.

Figure 1: Exchange rate movement under different regimes

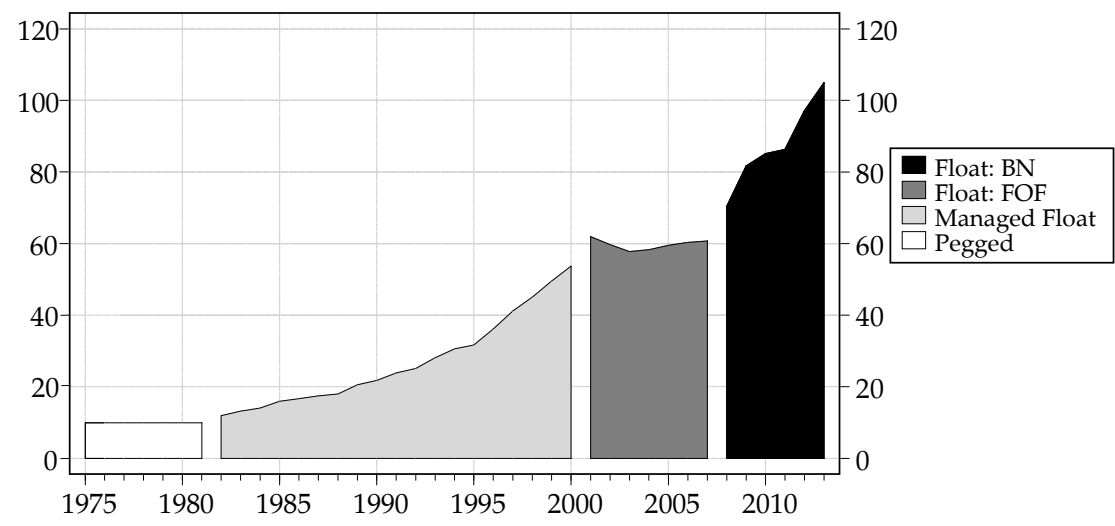

\subsection{Performance Analysis of Different Regimes}

Extending this analysis by looking at the performance of different regimes (in terms of outcome and macroeconomic and financial variables) could help the monetary authorities formulate an optimal exchange rate policy, given the country's economic idiosyncrasies. The foremost variable 
determining the health of any economy is the GDP growth rate. Although it is simplistic to believe that the exchange rate could solely determine overall GDP growth, Figure 2 and the corresponding regression results in Table 2 show that the slope coefficient of the exchange rate is not only negative but also highly significant with an explanatory power of 19 percent. It would, therefore, be unwise to entirely ignore the potential role of the exchange rate in determining this bottom-line variable.

Figure 2: OLS estimation of growth over exchange rate

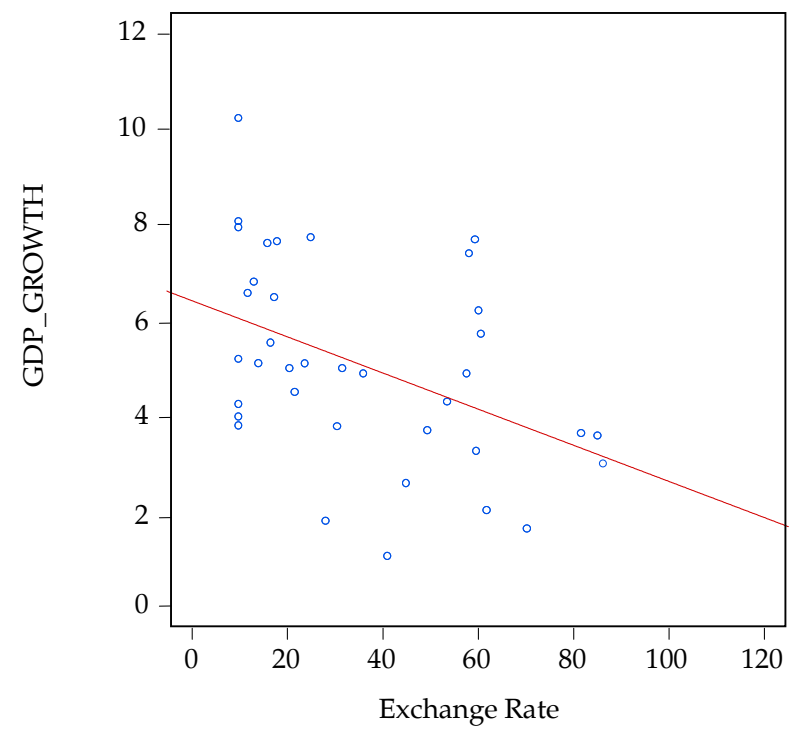

Table 2: Dependent variable: GDP_GROWTH

\begin{tabular}{lrcrc}
\hline Variable & Coefficient & SE & t-stat. & Prob. \\
\hline XRATE & -0.037924 & 0.013153 & -2.883225 & 0.0067 \\
C & 6.396717 & 0.567442 & 11.272900 & 0.0000 \\
R-squared & 0.191928 & Mean dependent var. & 5.038649 & \\
Adjusted R-squared & 0.168841 & SD dependent var. & 2.111224 & \\
SE of regression & 1.924760 & Akaike info criterion & 4.200018 & \\
Sum squared resid. & 129.664500 & Schwarz criterion & 4.287094 & \\
Log likelihood & -75.700330 & Hannan-Quinn criterion & 4.230716 & \\
F-statistic & 8.312989 & Durbin-Watson stat. & 1.634146 & \\
Prob. (F-statistic) & 0.006689 & & & \\
\hline
\end{tabular}

Source: Authors' estimates.

Table 3 presents the economic performance of Pakistan under different exchange rate regimes reflected by the average GDP growth rate for 
those periods. It is safe to say that the country's economic performance was impressive during the float FOF period with an average GDP growth rate of around 5.2 percent per annum. During the float-BN period, however, the GDP growth rate declined on average by almost 2.35 percent.

Table 3: GDP growth rates under different exchange rate regimes

\begin{tabular}{lcc}
\hline Regime & Mean & SD \\
\hline Float-BN & 2.923502 & 0.931532 \\
Float-FOF & 5.278538 & 2.094297 \\
Managed float & 4.975131 & 1.907178 \\
Pegged & 6.179820 & 2.535719 \\
All & 5.038649 & 2.111224 \\
\hline
\end{tabular}

Source: Authors' estimates.

Table 4 describes the current account balance as a percentage of GDP under different regimes. Clearly, the BN policy is associated with poor performance in the trade sector. Notwithstanding arguments concerning the causal relationship between the current account balance and exchange rate regime, it is worth pointing out that the high degree of FOF during 2001-07 is associated with the country's lowest average current account deficit (percentage of GDP). The period during which Pakistan followed a de jure free-floating regime, however, had severe consequences in the shape of a negative current account balance equivalent to almost 3.4 percent of GDP on average.

Table 4: Current account balance

\begin{tabular}{lcccc}
\hline & \multicolumn{2}{c}{ Nominal values (USD) } & \multicolumn{2}{c}{ Percent of GDP } \\
\cline { 2 - 5 } Regime & Mean & SD & Mean & SD \\
\hline Float-BN & $-5.81 \mathrm{E}+09$ & $6.65 \mathrm{E}+09$ & -3.462383 & 4.126803 \\
Float-FOF & $-1.45 \mathrm{E}+09$ & $4.91 \mathrm{E}+09$ & -0.428004 & 4.572595 \\
Managed float & $-1.54 \mathrm{E}+09$ & $1.11 \mathrm{E}+09$ & -3.196601 & 1.770231 \\
Pegged & $-8.47 \mathrm{E}+08$ & $1.52 \mathrm{E}+08$ & -4.500759 & 1.018332 \\
All & $-1.88 \mathrm{E}+09$ & $3.26 \mathrm{E}+09$ & -2.905154 & 2.923895 \\
\hline
\end{tabular}

Source: Authors' estimates.

Similarly disappointing results emerge with respect to other variables. The market capitalization of listed companies declined by almost 10 percent during the float-BN period (Figure 3). Inflation, one of the most critical variables determining the overall health of the economy and its 
future progress, almost doubled (to 13.2 percent) during the float-BN period when the de facto regime was put into practice (Figure 4). Not only did the level of inflation increase significantly, it also became more volatile, directly hampering the credibility of the monetary authorities. This increase in volatility along with high average inflation makes it difficult for consumers and investors to plan ahead and poses a significant threat to future development by increasing the cost of capital unnecessarily.

Figure 3: Average market cap of listed companies (percentage of GDP)

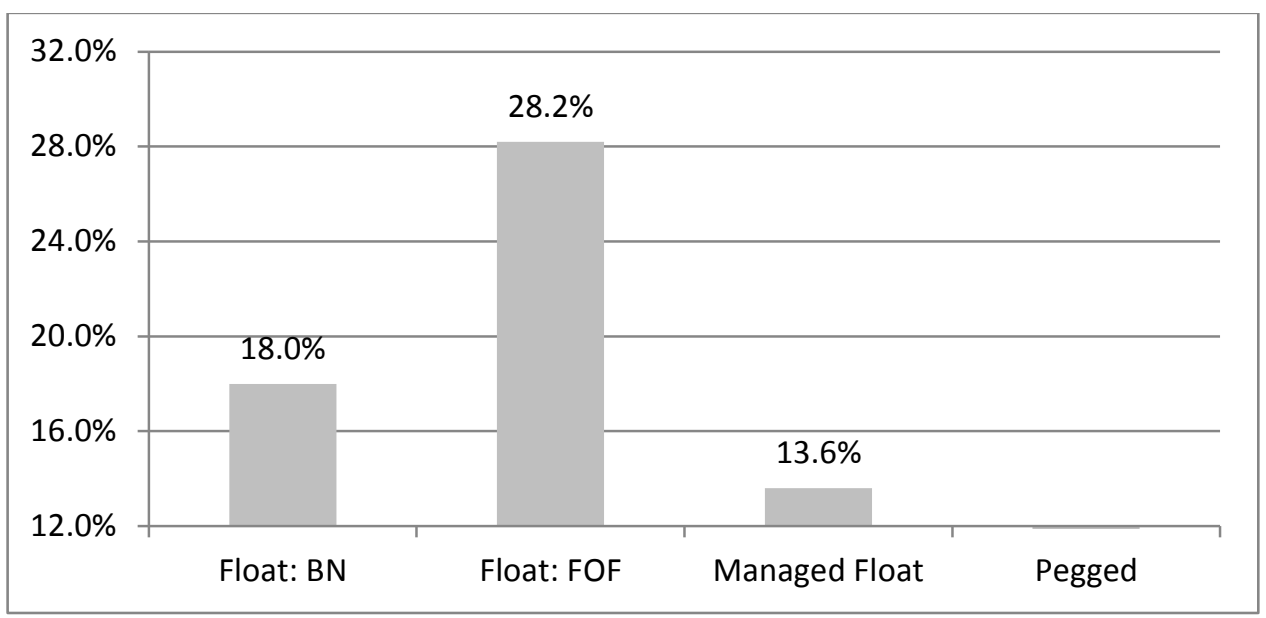

Figure 4: Average inflation under different regimes

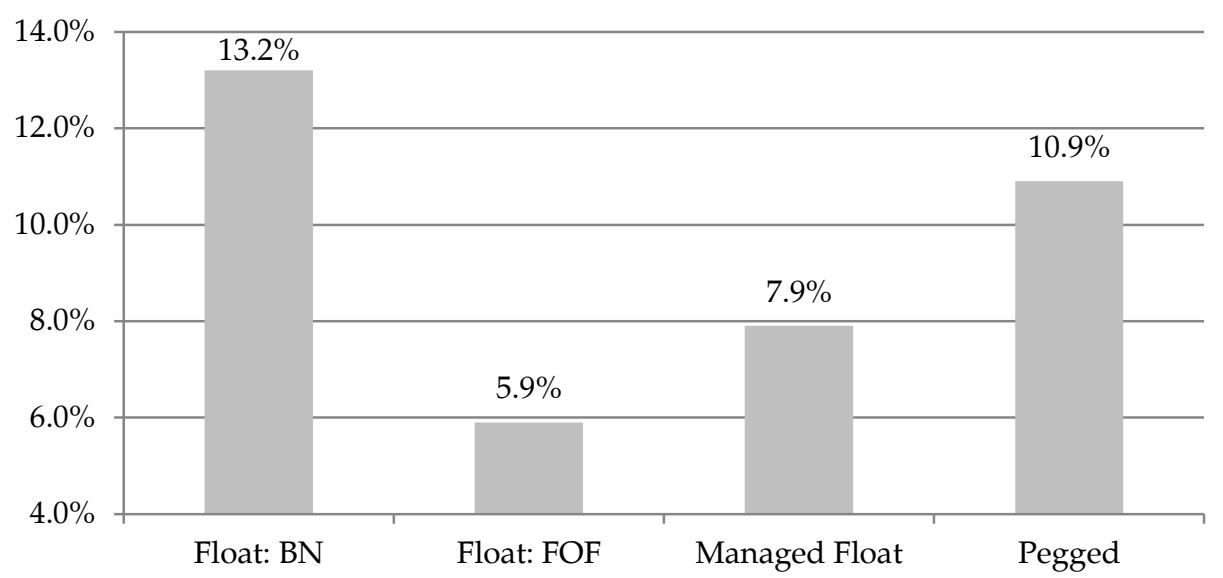

Another key variable is the volume of domestic savings. Figure 5 illustrates the disappointing performance of this variable during the period of benign neglect. 
Figure 5: Savings as a percentage of GDP vs. the exchange rate

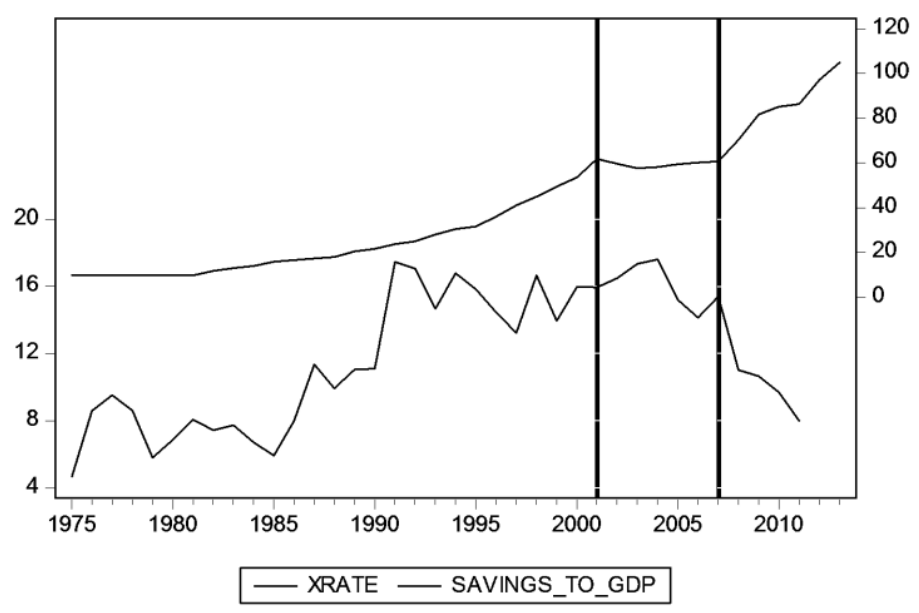

Savings declined sharply during the float-BN period when the rupee depreciated against the dollar. Almost 6 percent of GDP retained as savings, which could have translated into investment, evaporated (Table 5 ) because of the uncertain environment in the exchange rate market. This affected not only domestic savers and investors and compelled capital flight, but it also left foreign investors uncertain about the wisdom of investing in domestic assets. This negative perception among foreign investors is evident from the declining trend in net foreign direct investment (FDI), portfolio equity inflows, and gross capital formation (GCF) (Tables 6, 7, and 8, respectively).

Table 5: Savings as a percentage of GDP

\begin{tabular}{lcc}
\hline Regime & Mean & SD \\
\hline Float-BN & 9.846151 & 1.350556 \\
Float-FOF & 16.02370 & 1.228923 \\
Managed float & 12.39053 & 3.891199 \\
Pegged & 7.455923 & 1.734753 \\
All & 11.86925 & 4.027091 \\
\hline
\end{tabular}

Source: Authors' estimates. 
Table 6: Net FDI as a percentage of GDP

\begin{tabular}{lcc}
\hline Regime & Mean & SD \\
\hline Float-BN & 1.599760 & 1.174274 \\
Float-FOF & 1.765538 & 1.318932 \\
Managed float & 0.612804 & 0.362096 \\
Pegged & 0.215368 & 0.123201 \\
All & 0.880369 & 0.903620 \\
\hline
\end{tabular}

Source: Authors' estimates.

Table 7: Portfolio equity inflows as a percentage of GDP

\begin{tabular}{lcc}
\hline Regime & Mean & SD \\
\hline Float-BN & 0.022928 & 0.194964 \\
Float-FOF & 0.307788 & 0.440569 \\
Managed float & 0.250935 & 0.558014 \\
Pegged & 0.000000 & 0.000000 \\
All & 0.194833 & 0.459147 \\
\hline
\end{tabular}

Source: Authors' estimates.

Table 8: GCF as a percentage of GDP

\begin{tabular}{lcc}
\hline Regime & Mean & SD \\
\hline Float-BN & 17.22634 & 3.841086 \\
Float-FOF & 18.67048 & 2.661692 \\
Managed float & 18.63228 & 1.123026 \\
Pegged & 17.96139 & 1.015146 \\
All & 18.36059 & 1.855848 \\
\hline
\end{tabular}

Source: Authors' estimates.

\section{What Exactly Happened?}

The discussion above clearly illustrates the association between Pakistan's impressive economic performance and the float-FOF regime followed from 2001 to 2007-the period during which (we argue) the monetary authority adopted a pure float on a de jure basis but intervened significantly in the market on a de facto basis to keep the exchange rate stable. Given that the authority's designated mandate was different from its action, this section provides evidence to support our argument.

Following Levy-Yeyati and Sturzenegger's (2007) methodology, we develop an index to measure the intervention in the foreign exchange market based on changes in foreign exchange reserves relative to the 
monetary base of the economy. Although the methodology approximates intervention on the basis of changes in reserves over the prior 12 months, we calculate the intervention measure (IM) using Equation 1 on a yearly basis due to the absence of monthly data:

$$
I M=\frac{R_{t}-R_{t-1}}{M B_{t-1} / e_{t-1}}
$$

$R_{t}$ and $R_{t-1}$ are the values of foreign exchange reserves denominated in USD terms in the current and previous years. $e_{t-1}$ is the value of the monetary base denominated in the local currency (PKR) in the previous year and is the exchange rate between the rupee and the dollar in DC/FC format (direct quotation). Therefore, the IM is the yearly change in reserves as a percentage of the monetary base (with both denominated in the foreign currency).

Table 9 below gives descriptive statistics for the IM calculated using this methodology under different exchange rate regimes. Both the magnitude and sign under different regimes indicate the presence of FOF during 2001-07 (float-FOF) where the average yearly change in foreign exchange reserves is equal to 5.5 percent of the monetary base. The negative sign indicates that, on average, each year's reserves were smaller than the reserves of the previous year. The only explanation for this gradual decline in reserves at a time when the exchange rate was stable (at PKR 60 against $\$ 1$ ) is that the monetary authority intervened in the foreign exchange market to stabilize the supply of foreign currency by sacrificing the country's own reserves in order to halt or postpone domestic currency depreciation.

Table 9: Intervention through foreign exchange reserves

\begin{tabular}{lcc}
\hline Regime & Mean & SD \\
\hline Float-BN & 2.169026 & 6.965869 \\
Float-FOF & -5.499390 & 6.410043 \\
Managed float & -0.192059 & 3.179686 \\
Pegged & 0.382518 & 1.677876 \\
All & -0.865934 & 4.760767 \\
\hline
\end{tabular}

Source: Authors' estimates.

A counter-argument to this would be to ask whether the monetary authority was even capable of making such a large, successful intervention in the foreign exchange market to the extent that the exchange rate did not move beyond the average value of PKR 60 for almost seven years. However, the data suggest that the absolute as well as relative level of reserves (in 
terms of months of imports and as a percentage of GDP) were extremely high during this period (Tables 10 and 11). This would have helped the monetary authority intervene successfully.

Table 10: Foreign exchange reserves in terms of months of imports

\begin{tabular}{lcc}
\hline Regime & Mean & SD \\
\hline Float-BN & 3.765508 & 1.191607 \\
Float-FOF & 5.184935 & 1.695350 \\
Managed float & 1.949845 & 0.867383 \\
Pegged & 2.627308 & 0.214554 \\
All & 2.893541 & 1.624968 \\
\hline
\end{tabular}

Source: Authors' estimates.

Table 11: Foreign exchange reserves as a percentage of GDP

\begin{tabular}{lcc}
\hline Regime & Mean & SD \\
\hline Float-BN & 6.606003 & 1.578582 \\
Float-FOF & 9.623899 & 2.468907 \\
Managed float & 2.386589 & 1.566301 \\
Pegged & 2.498898 & 0.783996 \\
All & 4.233210 & 3.348625 \\
\hline
\end{tabular}

Source: Authors' estimates.

In Figure 6, we focus on the area that lies above the red horizontal line (the generally acceptable threshold of three months' import bills) and between the two vertical lines (the period occupied by FOF). This area corresponds exactly to the period for which Pakistan reported its highestever level of foreign exchange reserves. (Although beyond the scope of this paper, one factor that might explain the high level of reserves is the surge in foreign remittances that followed the $9 / 11$ attacks in the US.)

Figure 6: Foreign exchange reserves in terms of months of imports vs. the exchange rate
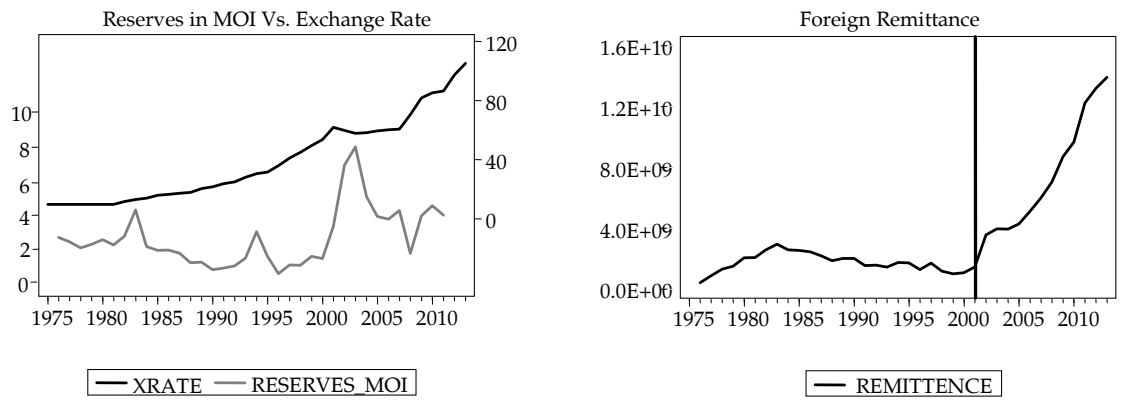
Rizvi, Naqvi, and Mirza (2013) provide sufficient evidence in favor of the existence of a de facto rupee-to-dollar peg during 1999-2009. Rizvi, Naqvi, and Bordes (2012) calculate a set of probabilities (Appendix 1) capturing the chances that the change in different variables falls outside the prespecified narrow interval during a specific period. Their findings also suggest that Pakistan has exhibited a high degree of FOF by intervening in the foreign exchange market not only through foreign exchange reserves but also through interest rates.

Figure 7 shows that the exchange rate is one of the most stable variables during the period studied, with a 93 percent probability that any monthly change will fall within the narrow band of $+/-2.5$ percent. However, this stability is at the cost of extreme volatility in interest rates and foreign exchange reserves, which show a 21 and 15 percent chance, respectively, that any monthly change will fall within the band of $+/-2.5$ percent. Rizvi et al. (2012) argue that the stability of the monetary base may be a result of the sterilization exercise conducted after the foreign exchange intervention to nullify its impact on the monetary base.

Figure 7: Stability of different variables, 2000-10

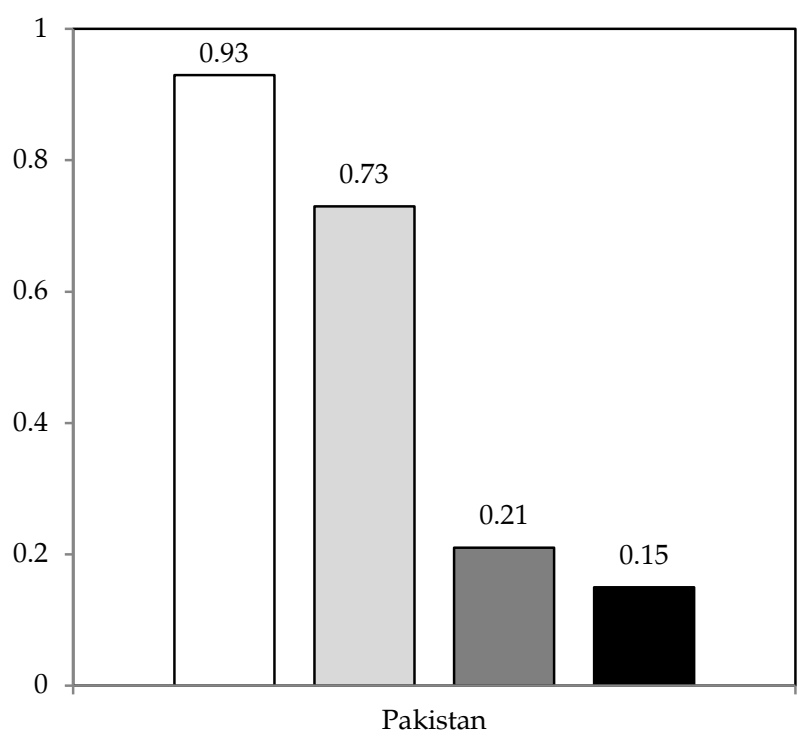

$\square$ Exchange Rate

$\square$ Monetary Base

$\square$ Interest Rates

- Foreign Exchange Reserves

Note: The figure depicts the probability of monthly changes falling within $a+/-2.5$ percent change band.

Source: Rizvi, Naqvi, and Bordes (2012). 


\section{Policy Implications and Conclusion}

What, then, might be an optimal exchange rate regime for Pakistan? As mentioned earlier, choosing an exchange rate regime is a complex matter, given the variations of fixed and floating regimes available and their associated advantages and disadvantages. It is equally important that, whatever policy the monetary authority deems fit to adopt, there should be no divergence between that stated policy and realtime implementation, otherwise it will affect the credibility of the policymakers.

The easiest choice lies at one extreme of the exchange rate flexibility spectrum: pegging. The merits of this regime should not be ignored, given that Pakistan is subject to the concept of original sin, i.e., the inability to borrow internationally in the domestic currency, ${ }^{2}$ exchange rate pass-through, inflation, and a huge trade deficit. Most of these problems could be resolved simply by opting for a fixed peg.

The strongest point in favor of pegging is that it can stabilize inflation if the domestic currency is pegged to a stable foreign currency. This is done in two ways: (i) by fixing that part of local inflation to the inflation of the base country that originates from traded goods and (ii) anchoring the expectations of local agents to the inflation of the base country (Mishkin, 1998). Pegging also tends to equalize interest rates in both economies, depending on the degree of commitment to making the peg credible. This could also induce more disciplined policymaking and encourage policymakers to avoid discretionary policies to achieve shortrun objectives - the time-inconsistency problem described by Kydland and Prescott (1977), Calvo (1978), and Barro and Gordon (1983).

Criticism of the policy of exchange rate pegging centers on the loss of an independent monetary policy, the transmission of external shocks, speculative attacks, and weakened accountability (Obstfeld \& Rogoff, 1995). In addition, Mishkin (1998) argues that pegging is inherently prone to full-fledged financial crises triggered by an exchange rate crisis when the peg breaks down. These arguments and the Asian financial crisis of 1997 ruled out the choice of pegging in general and of intermediate regimes (soft pegs) in particular, by blaming them as a fundamental reason for the crisis. This yielded the so-called "bipolar"

2 See Eichengreen, Hausmann, and Panizza (2007); Eichengreen and Hausmann (1999); Eichengreen, Panizza, and Borensztein (2008); Hausmann and Panizza (2003). 
prescription, i.e., a country should either opt for a hard peg or let the currency float freely.

However, as we have just analyzed in the case of Pakistan, a pure floating regime is not a solution to the country's problems (some of which we have mentioned above). This is why, even after officially adopting the regime in 2001, it was not implemented on a de facto basis for the next seven years. When, finally, Pakistan decided to fulfill its policy commitments in letter and spirit, the outcome was disastrous.

At this point, Pakistan would be ill advised to go against international financial institutions and the global community. Moreover, its policymakers are under pressure to opt for laissez-faire policies. The only conceivable solution then would be to adopt a managed float (Appendix 2). The monetary authority should declare that, in principle, it will not intervene in the foreign exchange market and allow market forces to freely determine the equilibrium exchange rate. However, it will retain the right to smooth exchange rate movements in order to curb any opportunistic drive by market manipulators or to stop any abrupt moves in the exchange rate that are not synchronized with the current situation or justified by the fundamentals. Such interventions will occur within prespecified thresholds or bands by taking action, including direct intervention if needed.

Many countries, such as Singapore, Bangladesh, Russia, Malaysia, and Switzerland, still follow similar "managed arrangements" (as termed by the IMF in its recent de facto classification of exchange rate regimes). ${ }^{3}$ Such arrangements are not only able to accommodate market-driven changes in the exchange rate continuously, but they also reassure market participants that no unjustified action will be allowed to drive the exchange rate away from its fundamental value.

\footnotetext{
${ }^{3}$ See http://www.imf.org/external/pubs/nft/2012/eaer/ar2012.pdf
} 


\section{References}

Barro, R. J., \& Gordon, D. B. (1983). A positive theory of monetary policy in a natural-rate model. Journal of Political Economy, 91, 589-610.

Calvo, G. (1978). On the time consistency of optimal policy in the monetary economy. Econometrica, 46(6), 1411-1428.

Calvo, G. A. (2000). Capital markets and the exchange rate with special reference to the dollarization debate in Latin America (Mimeo). College Park, MD: University of Maryland.

Calvo, G. A., \& Reinhart, C. M. (2002). Fear of floating. Quarterly Journal of Economics, 107(2), 379-408.

Eichengreen, B., \& Hausmann, R. (1999). Exchange rates and financial fragility (Working Paper No. 7418). Cambridge, MA: National Bureau of Economic Research.

Eichengreen, B., Hausmann, R., \& Panizza, U. (2007). Currency mismatches, debt intolerance and original sin: Why they are not the same and why it matters. In S. Edwards (Ed.), Capital controls and capital flows in emerging economies: Policies, practices, and consequences (pp. 121-170). Cambridge, MA: National Bureau of Economic Research.

Eichengreen, B., Panizza, U., \& Borensztein, E. (2008). Prospects for Latin American bond markets: A cross-country view. In E. Borensztein, Cowan, B. Eichengreen, \& U. Panizza (Eds.), Bond markets in Latin America: On the verge of a big bang? (pp. 247-290). Cambridge, MA: MIT Press.

Ghosh, A. R., \& Ostry, J. D. (2009). Choosing an exchange rate regime. Finance and Development, 46(4), 38-40.

Hausmann, R., \& Panizza, U. (2003). On the determinants of original sin: An empirical investigation. Journal of International Money and Finance, 22(7), 957-990.

Khan, M. A., \& Qayyum, A. (2007). Exchange rate determination in Pakistan: Evidence based on purchasing power parity theory. Pakistan Economic and Social Review, 45(2), 181-202. 
Kydland, F. E., \& Prescott, E. C. (1977). Rules rather than discretion: The inconsistency of optimal plans. Journal of Political Economy, 85, 473491.

Levy-Yeyati, E., \& Sturzenegger, F. (2007). Fear of appreciation (Policy Research Working Paper No. 4387). Washington, DC: World Bank.

McKinnon, R., \& Schnabl, G. (2004). The East Asian dollar standard, fear of floating, and original sin. Review of Development Economics, 8(3), 331-360.

Mishkin, S. F. (1998, June). Exchange-rate pegging in emerging-market countries? (Mimeo). Retrieved from http://www0.gsb.columbia.edu/faculty/fmishkin/PDFpapers/I F98.pdf

Mishkin, F. S. (2000). Inflation targeting in emerging market countries (Working Paper No. 7618). Cambridge, MA: National Bureau of Economic Research.

Mishkin, F. S. (2004). Can inflation targeting work in emerging market countries? In Festschrift in honor of Guillermo A. Calvo, April 15-16, 2004. Washington, DC: International Monetary Fund.

Obstfeld, M., \& Rogoff, K. (1995). The mirage of fixed exchange rates. Journal of Economic Perspectives, 9(4), 73-96.

Rizvi, S. K., Naqvi, B., \& Bordes, C. (2012). Reassessment of exchange rate flexibility and fear of floating in Asia: How much credible are the benchmark floaters? (Mimeo). Retrieved from http://www.alde.es/encuentros/anteriores/xiveea/trabajos/k/p df/041.pdf

Rizvi, S. K., Naqvi, B., \& Mirza, N. (2013). Choice of anchor currencies and dynamic preferences for exchange rate pegging in Asia. Lahore Journal of Economics, 18(2), 37-49. 


\section{Appendix 1}

Following the methodology of Calvo and Reinhart (2002), Rizvi et al. (2012) calculate the probabilities of confining a percentage change within a prespecified narrow band for different variables (Equations 1 to 4). As Calvo and Reinhart (2002) have shown (substantiated by Rizvi et al., 2012), the calculated probability is an increasing function of rigidity for the exchange rate and a decreasing function for reserves, base money, and the domestic interest rate.

The structure of the methodology is as follows:

$$
\begin{aligned}
& P\left(L B \leq E^{P C} \leq U B \mid P e g\right)>P\left(L B \leq E^{P C} \leq U B \mid \text { Float }\right) \\
& P\left(L B \leq R^{P C} \leq U B \mid P e g\right)<P\left(L B \leq R^{P C} \leq U B \mid \text { Float }\right) \\
& P\left(L B \leq M^{P C} \leq U B \mid \text { Peg }\right)<P\left(L B \leq M^{P C} \leq U B \mid \text { Float }\right) \\
& P\left(L B \leq i^{C} \leq U B \mid \text { Peg }\right)<P\left(L B \leq i^{C} \leq U B \mid \text { Float }\right)
\end{aligned}
$$

Left hand side of each equation represents a probability of staying a change within a pre-defined narrow interval for different variables given that country is observing fixed or pegged regime. Right hand side is the same probability for floating regimes. LB and UB are lower and upper bound for the narrow interval which is set as $2.5 \%$ for equation 1,2 and 3 and 50 basis points $(0.5 \%)$ for equation $4 . E^{P C}, R^{P C}$, and $M^{P C}$ are percentage change in Exchange rate, Reserves and Base Money respectively, calculated as difference in the natural logarithms of concerned series:

$$
\% \Delta x=\ln x_{t}-\ln x_{t-1}=\frac{x_{t}-x_{t-1}}{x_{t-1}}
$$

And $i^{C}$ is the change in interest rate calculated as $\Delta i=i_{t}-i_{t-1}$. 


\section{Appendix 2}

\section{Scoring matrix}

\begin{tabular}{|c|c|c|c|c|c|c|c|c|c|c|c|}
\hline Period & 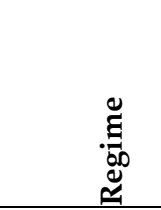 & 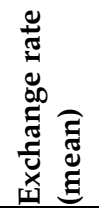 & $\begin{array}{l}5 \\
3 \\
0 \\
0 \\
0 \\
0 \\
0 \\
0\end{array}$ & 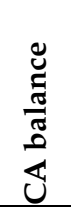 & 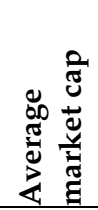 & 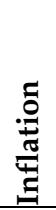 & 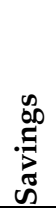 & 宝 & 牙 & Uु & 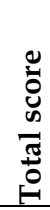 \\
\hline $2008-13$ & Float-BN & 2 & 1 & 2 & 3 & 1 & 2 & 3 & 2 & 1 & 17 \\
\hline 2001-07 & Float-FOF & 3 & 3 & 4 & 4 & 4 & 4 & 4 & 4 & 4 & 34 \\
\hline $\begin{array}{l}1982- \\
2000\end{array}$ & $\begin{array}{l}\text { Managed } \\
\text { float }\end{array}$ & 1 & 2 & 3 & 2 & 3 & 3 & 2 & 3 & 3 & 22 \\
\hline $1975-81$ & Pegged & 4 & 4 & 1 & 1 & 2 & 1 & 1 & 1 & 2 & 17 \\
\hline
\end{tabular}

The above matrix has been developed to help understand the comparative performance of the four regimes identified earlier: pegged, managed float, pure float (with FOF), and pure float (with $\mathrm{BN}$ ). The rating scale used is from 1 to 4 ( 1 being the worst performing regime and 4 being the best performing regime). It is clear that Pakistan's economic managers performed best when strictly controlling the exchange rate market while simultaneously claiming it was a pure float (i.e., FOF behavior). However, given that international financial institutions and investors tend not to look kindly on FOF, the second-best option remains the managed float. 